\title{
Relationship between Trichomonas vaginalis and malignant cell in cervix in Babylon city
}

\author{
Maher A. Al-Quraishi ${ }^{1}$, Raflaa S.H. Hussian ${ }^{2}$, Sura I. A. Jabuk ${ }^{3}$, \\ Susan I. A. Jabuk ${ }^{4}$ \\ 1,2,3 University of Babylon, College of science, Department of Biology, Hilla, Iraq 4,Alhilla teaching hosbital \\ Babylon health directorate
}

\begin{abstract}
Samples were collected during the period from 1/2 to 15/6 from some private clinics in the province of Babylon of women who suffer from frequent infections in the genital tract and urinary for the purpose of knowing the relationship between parasite Trichomonas vaginalis and Malignant cells.Current study included (250) samples cervical swap, the samples were examined by a wet swab and centrifugation, also examined samples mediated Pap smear was incidence of (20\%) mediated wet swab and (22\%) mediated centrifuge without significant differences while we did not notice the presence of malignant cells mediated by Pap smear. The study involved measuring the rate of iron and calcium in the blood, was the rate of iron $(55.30 \mu \mathrm{g} / \mathrm{dl})$, while the rate of calcium was $(9.10 \mathrm{mg} / \mathrm{dl})$ without significant differences.
\end{abstract}

Key words: Trichomonas vaginalis; Iron; Calcium; Pap smear.

\section{Introduction:}

Trichomonas vaginalis, a motile protozoan, is the most common curable sexually transmitted infection (STI) worldwide, with an estimated 174 million new cases ayear, of which 154 million occur in resource limited settings. Whereas up to one-third of cases of T. vaginalis in females are thought to be asymptomatic, the majority develop symptoms and signs of vaginal discharge (clear to mucopurulent), vulval irritation and inflammation. Some females also describe lower abdominal pain and dysuria (1). Additionally, infection by this parasite is associated with the development of cervical cancer $(2,3)$. T. vaginalis need to adhere to the host cell transiently prior to invasion, adhesion of the extracellular pathogen, iron is required for the parasite to both establish and maintain infection, and thus host cell receptors play a critical role throughout infection (4). Iron is an important component of the host environment, and we have recently shown that iron regulates a variety of trichomonal properties. Most significant was the demonstration that iron regulated the gene expression of surface immunogensand adhesins. Calcium is necessary for normal function of various systems, $(5,6)$ Improving calcium and vitamin D nutritional status substantially reduces all-cancer risk in postmenopausal women. (7) The Pap smear/test or cervicovaginal smear was initially introduced to medical practice by Papanicolaou and Traut in 1943. Since that time the test was gradually adopted worldwide and it proved to be the most successful screening test to detect premalignant and malignant lesions of the uterine cervix. It has been credited to the decreased incidence of invasive cervical cancers from 32.6 in 1940s to 8.3 per 100,000 women in 1983 and 1984 in the United States. However, cervical cancer is far from being radicated as about 12,710 new cases are expected to be diagnosed in 2011therefore, plays an important role in the current cervical cancer screening. (8) .In general, microorganisms living within a mammal especially $\mathrm{T}$. vaginalis need iron to growth.

\section{Material and methods:}

Samples were collected during the period from $1 / 2$ to $15 / 6$ from some private clinics in the province of Babylon from Married women who suffer from frequent infections in the genital tract and urinary been getting 250 swap examined for detecting the presence of the parasite. Swap is checked mediated by Wet mount as placed on slide, Drop from Normal Saline, then moisten a cotton ball in one of the ends of the swab then check up under microscope .(9)

Using the samples in the plan tube after it has been on the investigation of parasite, before that using $2 \mathrm{ml}$ of glucose saline in plan tube and made centrifugation for samples then let the filtrate and retained Sediment, is placed on a slide and then put the Cover slip on the slide, and then examined under a microscope to diagnose the presence of the parasite. and calcium.

Samples were collected from the blood and the work of centrifuges to get her to investigate serum iron

Iron and calcium, analyzed by atomic absorption spectroscopy (AAS) For iron estimation, serum was treated with one volume of $20 \%(\mathrm{w} / \mathrm{v})$ trichloro acetic acid (TCA) and heated to ensure release of transferrin 
bound iron and then centrifuged. The supernatant was diluted with 3 volumes of deionized water and then analyzed by AAS at 248.3. (10)

While 250 were examined another sample mediated by Pap smear.(11)

Statistical analysis

P-values $<0.05$ were considered as statistically significant.

Statistical analysis was performed using SPSS statistical software (12).

\section{Results:}

Samples were taken from married women who suffer from frequent infections in the genital tract and urinary of different ages was the proportion of infection $(20 \%)$ by wet mount while the proportion of infection by centrifugation $(22 \%)$ and no significant differences were observed as shown in Table (1).

Table 1: shows the proportion of infection of Trichomonas vaginalis by wet swab manner and method of

\begin{tabular}{|c|c|c|}
\multicolumn{4}{|c|}{ centrifugal } \\
\hline No. $=250$ & Infective $(\%)$ & Non infective $(\%)$ \\
\hline Wet mount & $50(20)$ & $200(80)$ \\
\hline Centrifugation & $55(22)$ & $195(78)$ \\
\hline
\end{tabular}

$$
\mathrm{p}>0.05
$$

Serum nutrients were measured in infected women compared to non-infected women, the rate of calcium of infected women was (9.10) higher than non-infected (8.91) without significant differences while the rate of iron of infected was (55.30) less from non-infected (88.09) and no significant differences were observed as shown in Table (2).

Table (2): Mean of serum nutrients in women with Trichomonas vaginalis by wet mount

\begin{tabular}{|c|c|c|}
\hline Parameter & Infective with Trichomonas vaginalis $(\mathrm{n}=50)$ & non infective \\
\hline Calcium $(\mathrm{mg} / \mathrm{dl})$ & $9.10 \pm 0.20$ & $8.91 \pm 0.31$ \\
\hline Iron $(\mu \mathrm{g} / \mathrm{dl})$ & $55.30 \pm 4.01$ & $88.09 \pm 7.9$ \\
\hline
\end{tabular}

Values are mean \pm standard error (SE). $\mathrm{p}>0.05$

Exam samples taken from women with Pap smear screening for malignant cells have not been found on these cells.

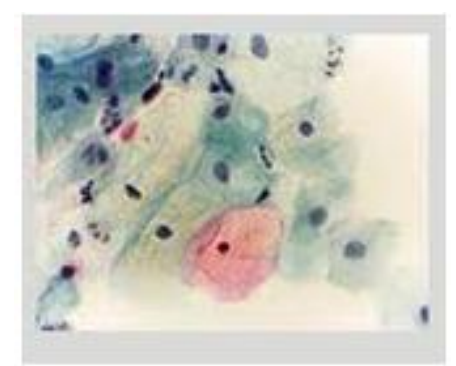

Figure 1: shows normal Pap smear.

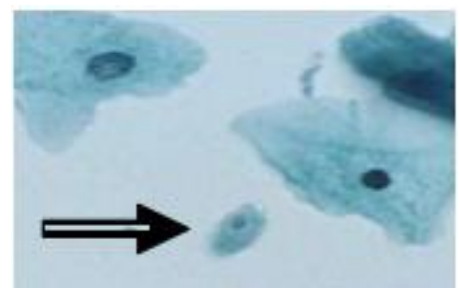

Figure 2: shows Trichomonas vaginalis in vaginal secretion.

\section{Disscution}

T. vaginalis parasite is protozoa, flagellated, anaerobic and is one of the primary pathogens that infect men and women alike. This causes the Trichomonaiasis which is one of Sexually Transmitted Diseases (STDs) may include infection by a group of symptoms, which may not appear clearly has an impact on the long term when the infection, particularly among women(13). In the current study, were compared with the diagnosis of parasite by wet mount and centrifugal infection rate was $(20 \%)$ wet mount while the infection rate in a centrifuge $(22 \%)$ and without significant differences. this result was match with another study (22.8\%) (14). While this result was higher than another study (18.4\%) (15).Micronutrients such as calcium and iron play an 
integral part in both cell mediated and humoral immunity .Iron are important minerals for several enzymes and metabolic pathways. Iron deficiencies impair cell mediated immunity, delayed hypersensitivity and leukocyte functions (16). Iron is essential nutrient for Trichomonas vaginalis and plays a pivotal role in the establishment of infection, proliferation and virulence (17). In this study was measured the rate of iron and calcium in serum found that the percentage of iron $(55.30 \mu \mathrm{g} / \mathrm{dl})$ which was more than normal rate $(60 \mu \mathrm{g} / \mathrm{dl})$ while not noticed a change in the rate of calcium $(9.10 \mathrm{mg} / \mathrm{dl})$ in the blood without significant differences normal value is (8$10.5 \mathrm{mg} / \mathrm{dl}) .(18)$

A Pap test is a test of a sample of cells taken from a woman's cervix or vagina. The test is used to look for changes in the cells of the cervix and vagina that show cancer or conditions that may develop into cancer. In this study we don't find any changes. (11)

\section{Refrences}

[1]. Sena AC, Miller WC, Hobbs MM. (2007). Trichomonas vaginalis infection in male sexual partners: implications for diagnosis, treatment, and prevention. Clin Infect Dis; 44:13-22.

[2]. Viikki, M., Pukkala, E., Nieminen, P., and Hakama, M. (2000) Gynaecological infections as risk determinants of subsequent cervical neoplasia. Acta Oncol 39: 71-75.

[3]. Zhang, Z.F., and Begg, C.B. (1994) Is Trichomonas vaginalis a cause of cervical neoplasia? Results from a combined analysis of 24 studies. Int J Epidemiol 23: 682-690.

[4]. Okumura, C. Y. M., Baum, L. G. and Johnson, P. J. (2008), Galectin-1 on cervical epithelial cells is a receptor for the sexually transmitted human parasite Trichomonas vaginalis. Wiley J . 45

[5]. Iannotti L.L. , Brien K.O., Chang,S.C., Mancini,J., Nathanson,M.S., Liu,S., Harris,Z.L. and Witter, F.R. (2005), Iron Deficiency Anemia and Depleted Body Iron Reserves Are Prevalent among Pregnant African-American Adolescents. The American Society for Nutritional Sciences. 8

[6]. Lemos P.A.P. ,Ocorrência da infecção por Trichomonas vaginalis em mulheres HIV positivas e negativas atendidas em hospitais de referência em Goiânia. Rev Patol Trop. 2009;38(1):71-2.

[7]. Lappe, J.M. , Travers-Gustafson, D., Davies, K.M., Recker ,R.R., Heaney, R.P.Vitamin D and calcium supplementation reduces cancer risk: results of a randomized trial. Am J Clin Nutr. 2007 Jun;85(6):1586-91.

[8]. Smith,B. and Nguyen, G.K. (2012), Pap Smear and Breast Cytology Library and Archives Canada .83

[9]. 9. Nasir, J.A.; Najam, J. ;Tahir, F. ;Asghar, M.N.\& Iqbal, J.(2005). Trichomonas vaginalis in vaginal smears of women using Interauterine Contraceptive Device .Pak. J. Med. Res.; 44(3):144-116.

[10]. Hemalatha, R., Ramalaxmi,B.A., Swetha, G.A., Rao,D.M., Charyulu,S. and Kumar ,D.(2012), Nutritional status, bacterial vaginosis and cervical colonization in women living in an urban slum in India.National Institute of Nutrition.24

[11]. Moyer, V.A.(2012). Screening for cervical cancer: U.S. Preventive Services Task Force recommendation statement. Annals of internal medicine 156 (12): 880-91

[12]. AL-Rawi,G.M.(1989),AL-madghel ila AL-Ihsaa. Ministry of Higher Education and Scientific Research. Mosul University.

[13]. Soper, D. (2004). Trichomoniasis: under control or undercontrolled. American journal of obstetrics and gynecology; 190 (1): 28190.

[14]. Franceschi, S.; Rajkumar, R.; Snijders, P.J.F.; Arslan, A.; Mahe, C.;Plummer, M.; Sankaranarayanan, R. ;Cherian, J.; Meijer, C.J.L.M. \& Weiderpass, E.(2005), Papillomavirus infection in rural women in southern India. British Journal of Cancer; $92: 601$ 606.

[15]. Leôncio de Lima,M.C., Albuquerque,T.V., Barreto Neto,A.C.,anMd Rehn,V.N.C.(2013), Prevalence and independent risk factors for trichomoniasis in women receiving primary health care Universidade Federal de Pernambuco, Vitória de Santo Antão, PE, Brazil.4(26)

[16]. Bhaskaram, P., (1997). Nutrition and Immune response. In Textbook of Human Nutrition, eds Mehtab S Bamji, N Pralhad Rao and Vinodini Reddy. 16: 211-219.

[17]. Lehker ,M.W.and Alderete, J.F.(1992), Iron regulates growth of Trichomonas vaginalis and the expression of immunogenic trichomonad proteins. Mol Microbiol. 6: 123-32.

[18]. A manual of laboratory and diagnostic tests edition 8 Fichbach,f.t. and Dunning .M.B.(2009) 